УДК 342.92(477)

https://doi.org/10.34142/23121661.2019.30.14

orcid.org/0000-0003-0236-7327

(C) Магаррамлі Е.В., 2019

\title{
E.В. Магаррамлі
}

\section{СИСТЕМАТИЗАЦІЯ ПРИНЦИПІВ НАДАННЯ БЕЗОПЛАТНОЇ ПРАВОВОЇ ДОПОМОГИ В УКРАЇНІ}

\section{E. Maharramli \\ SYSTEMATIZATION \\ OF PRINCIPLES OF FREE LEGAL AID IN UKRAINE}

\begin{abstract}
Анотація. Автором запропоновано два підходи щодо систематизації принципів надання правової допомоги. Перший підхід будується на підставі нормативно закріплених засад, котрі переважно відображають державну політику в даній сфері. Другий підхід уособлює широку систему надання безоплатної правової допомоги, котра складається 3 наступних елементів: 1) загальноправові (конституційні) принципи; 2) галузеві принципи; 3) принципи державної політики у сфері надання безоплатної правової допомоги; 4) суб'єктивні принципи; 5) міжнародні принципи та стандарти надання правової допомоги.

Ключові слова: принципи, безоплатна правова допомога, первинна безоплатна правова допомога, вторинна безоплатна правова допомога, принципи права, правові послуги.
\end{abstract}

Аннотация. Автором предложены два подхода к систематизации принципов оказания правовой помощи. Первый подход строится на основании нормативно закрепленных основ, отражающих государственную политику в данной сфере. Второй подход олицетворяет широкую систему предоставления бесплатной правовой помощи, которая состоит из следующих элементов: 1) общеправовые (конституционные) принципы, 2) отраслевые принципы, 3) принципы государственной политики в сфере предоставления бесплатной правовой помощи; 4) субъективные принципы, 5) международные принципы и стандарты оказания правовой помощи.

Ключевые слова: принципы, бесплатная правовая помощь, первичная бесплатная правовая помощь, вторичная бесплатная правовая помощь, принципы права, правовые услуги.

Annotation. The author proposes two approaches to systematizing the principles of legal assistance. The first approach is based on regulatory frameworks reflecting government policy in this area. The second approach represents a broad system of providing free legal aid, which consists of the following elements: 1) general legal (constitutional) principles, 2) industry 
principles, 3) principles of state policy in the field of providing free legal aid; 4) subjective principles; 5) international principles and standards of legal assistance.

Key words: principles, free legal aid, primary free legal aid, secondary free legal aid, principles of law, legal services.

Постановка проблеми. Впровадження концепції «людиноцетризму» в публічному адмініструванні не може обмежуватись лише декларуванням людини як центральної постаті в державі, недостатньо і iï декларування як найвищої соціальної цінності. Натомість в процесі публічного адміністрування державними сферами важливо враховувати громадську думку громадян i спиратись на інтереси населення. Інтереси держави повинні грунтуватись на реальних потребах населення, виключають суб'єктивізм, реалізацію особистих інтересів посадових осіб під егідою суцільної необхідності. В такому контексті особливої уваги під час реформування потребувала правоохоронна сфера, яка включає декілька напрямів, серед яких: правосуддя, правоохоронна діяльність, а також захист прав і свобод людини, причому оновлення потребували всі напрями.

В той же час процес реформування як і будь-який інший повинен грунтуватись на фундаментальних основах, до яких можна віднести: теоретичні здобутки; національний і зарубіжний досвід втілення окремих заходів і наслідків прийняття рішень; думки провідних фахівців-юристів; мати відповідну правову основу, тобто правові норми, що регламентують порядок проведення змін, котрі позначаються на функціонуванні того чи іншого інституту, обумовлюють впровадження нових організаційних і правових засад його роботи, що часто призводить до формування абсолютно нової системи як у випадку вдосконалення інституту безоплатної правової допомоги. Одночасно необхідно розуміти, що не можливо побудувати нову систему на основі вже існуючих засад (правових положень, ідей і поглядів), а тому процес реформування передбачає систематичну реалізацію значної кількості заходів спрямованих на впровадження концептуально нових підходів до формування та роботи інститутів, зокрема інституту безоплатної правової допомоги. Часто такі підходи мають особливу зовнішню форму - принципів, котрі часто в подальшому отримують законодавче закріплення.

Стан опрацювання. Зважаючи на те, що система принципів надання безоплатної правової допомоги не знайшла свого відображення в наукових працях учених у галузі юриспруденції, в основу даного дослідження було покладено загальнотеоретичні положення щодо принципів права, які знайшли відображення в роботах таких вчених як: І.П. Бахновська, О.В. Зайчук, В.К. Колпаков, Ю.С. Шемшученко та ін.

Мета статті полягає в систематизації принципів надання безоплатної правової допомоги, для чого необхідно з'ясувати юридичний зміст понять «принцип» та «принципи права», а також проаналізувати чинні нормативно- 
правові акти, в яких закріплено принципи надання безоплатної правової допомоги.

Виклад основного матеріалу. Буквально принцип означає вихідне начало чи певну основу [1, с. 547], одночасно його тлумачать як : «наукове чи моральне начало, основу, правило, від якого не відступають» [2, с. 431]; «основне вихідне положення якої-небудь наукової системи, теорії, ідеологічного напряму і т. ін.» або «особливість, покладену в основу створення або здійснення чого-небудь, спосіб створення або здійснення чогось» [3, с. 1125]. Це загальні розуміння даного поняття, які були уточнені науковцями у сфері юриспруденції, внаслідок чого поняття «принцип» отримало наступні значення: «1) основні засади, вихідні ідеї, що характеризуються універсальністю, загальною значущістю, вищою імперативністю і відображають суттєві положення теорії, вчення, науки, системи внутрішнього і міжнародного права, політичної, державної чи громадської організації (гуманізм, законність, справедливість, рівність громадян перед законом тощо); 2) внутрішнє переконання людини, що визначає її ставлення до дійсності, суспільних ідей і діяльності» [4, с. 110-111]. Будучи утворюючою основою системи права, принципи «охоплюють всю правову матерію - i iдеї, і норми, і відносини, а також надають їй логічності, послідовності, збалансованості. У принципах права синтезується світовий досвід розвитку права, досвід цивілізації» [5, с. 22].

Принципи права закріплені в нормативно-правових актах різної юридичної сили, що проходять довгий процес становлення та уособлюють в собі соціальні ідеї та суспільні ідеали та «характеризуються нормативністю й найвищою стабільністю, високим рівнем узагальнення й абстрагування, фундаментальністю, що дозволяє їм виконувати регулятивну, системоутворювальну, інформаційну, правовиховну, пізнавальну й ціннісну функції» [6, с. 21]. Принципи права не тільки є основою правоутворення та право реалізації, а і розкривають сутність і основне призначення того об'єкту (системи), якому вони притаманні.

3’ясувавши юридичну природу принципів і їх значення, надалі необхідно охарактеризувати процес надання правової допомоги, насамперед для того, що б правильно встановити ті принципи, які складають його основи. Надання безоплатної правової допомоги - це багатокомпонентний процес, котрий складається з великої кількості дій і операцій, які здійснюються сукупністю уповноважених суб'єктів у межах надання правових послуг. Останні включають «надання правової інформації, консультацій і роз'яснень 3 правових питань; складення заяв, скарг, процесуальних та інших документів правового характеру; здійснення представництва інтересів особи в судах, інших державних органах, органах місцевого самоврядування, перед іншими особами; забезпечення захисту особи від обвинувачення; надання особі допомоги в забезпеченні доступу особи до вторинної правової допомоги та медіації» [7] (п. 4 ч. 1 ст. 1 Закон України «Про надання безоплатної правової допомоги»). Наведене визначення дає підстави говорити про те, що принципам надання безоплатної 
правової допомоги притаманний дуалістичний характер: $з$ одного боку це велика кількість принципів, на яких будується і здійснюється надання безоплатної правової допомоги, з іншого - лише ті організаційно-правові засади, на основі яких здійснюється адміністрування даною сферою.

Якщо розглядати принципи надання безоплатної правової допомоги у площині адміністрування правоохоронною сферою, де остання розуміється в широкому сенсі, і включає право на професійну правничу допомогу, передбачене ст. 59 Основного закону держави [8], то з урахуванням забезпечення державою вказаного конституційного права до принципів надання безоплатної правової допомоги необхідно віднести засади, закріплені у спеціалізованому правовому акті: «1) верховенство права; 2) законність; 3) доступність безоплатної правової допомоги; 4) забезпечення якості безоплатної правової допомоги; 5) гарантоване державне фінансування» [7]. Як бачимо, даний перелік містить як загально-правові принципи (верховенство права та законність), так і виключно ті, що притаманні інституту безоплатної правової допомоги (доступність безоплатної правової допомоги, забезпечення якості безоплатної правової допомоги, гарантоване державне фінансування).

Проте, на нашу думку, сама система таких принципів є значно ширшою, оскільки процес їі організації та здійснення не може будуватись виключно на засадах діяльності держави (державної політики). Надання безоплатної правової допомоги - це сукупність численної кількості процесів і процедур, що реалізуються різними суб'єктами. В той же час перелік із п'яти принципів не може бути покладено в основу такого масштабного процесу. У такому сенсі ми вважаємо, що система (сукупність) принципів надання безоплатної правової допомоги повинна включати елементи (групи принципи), до яких слід віднести:

1) загальноправові (конституційні) принципи;

2) галузеві принципи;

3) принципи державної політики у сфері надання безоплатної правової допомоги;

4) суб'єктивні принципи;

5) міжнародні принципи та стандарти надання правової допомоги.

Зробимо застереження, що побудова системи принципів надання безоплатної правової допомоги та дослідження іiі окремих елементів може бути предметом самостійного дослідження монографічного характеру. Враховуючи поставлену нами мету даної наукової роботи, обмежимось лише короткою характеристикою таких елементів, визначивши цей напрям як перспективний для здійснення подальших наукових пошуків.

Загальноправові або конституційні принципи як основоположні засади організації функціонування даного інституту закріплені в низці статей Основного закону держави: принципи пріоритету прав і свобод людини, поваги до їх честі та гідності (ст. 3); принцип верховенства права (ст. 8); принцип закон- 
ності (ч. 2 ст. 19); принцип презумпції невинуватості (ст. 62); принцип рівності громадян перед законом (ст. 24); принцип обмеження зворотної дії законів (ст. 58) [8].

Галузеві принципи відображають основні засади надання безоплатної правової допомоги в тій чи іншій правовій галузі права - кримінальній, адміністративній, цивільній тощо. Такі принципи знаходять своє відображення у відповідних процесуальних нормативно-правових актах, які регламентують порядок здійснення провадження в кримінальних, адміністративних, цивільних справах і проваджень у справах про адміністративні правопорушення. Так, згідно з ч. 1 ст. 7 Кримінального процесуального кодексу, кримінальне провадження здійснюється на підставі наступних принципів: «1) верховенство права; 2) законність; 3) рівність перед законом і судом; 4) повага до людської гідності; 5) забезпечення права на свободу та особисту недоторканність; 6) недоторканність житла чи іншого володіння особи; 7) таємниця спілкування; 8) невтручання у приватне життя; 9) недоторканність права власності; 10) презумпція невинуватості та забезпечення доведеності вини; 11) свобода від самовикриття та право не свідчити проти близьких родичів та членів сім’ї; 12) заборона двічі притягувати до кримінальної відповідальності за одне й те саме правопорушення; 13) забезпечення права на захист; 14) доступ до правосуддя та обов'язковість судових рішень; 15) змагальність сторін та свобода в поданні ними суду своїх доказів і у доведенні перед судом їх переконливості; 16) безпосередність дослідження показань, речей і документів; 17) забезпечення права на оскарження процесуальних рішень, дій чи бездіяльності; 18) публічність; 19) диспозитивність; 20) гласність і відкритість судового провадження та його повне фіксування технічними засобами; 21) розумність строків; 22) мова, якою здійснюється кримінальне провадження» [9].

Принципами адміністративного судочинства є: принцип верховенства права; принцип рівності усіх учасників судового процесу перед законом і судом; принципи змагальності сторін, диспозитивності та офіційного з'ясування всіх обставин у справі; принцип гласності судового процесу; принцип відкритості інформації щодо справи; принцип оскарження судового рішення; принцип обов'язковості судових рішень; принцип мови судочинства та діловодства в адміністративних судах [10].

Цивільне судочинство здійснюється на підставі принципів: «1) верховенства права; 2) поваги до честі і гідності, рівності усіх учасників судового процесу перед законом та судом; 3) гласності і відкритості судового процесу та його повне фіксування технічними засобами; 4) змагальності сторін; 5) диспозитивності; 6) пропорційності; 7) обов'язковості судового рішення; 8) забезпечення права на апеляційний перегляд справи; 9) забезпечення права на касаційне оскарження судового рішення у випадках, встановлених законом; 10) розумності строків розгляду справи судом; 11) неприпустимості зловживання процесуальними правами; 12) відшкодування судових витрат сторони, на користь якої 
ухвалене судове рішення» [0] (ч. 3 ст. 2 Цивільного процесуального кодексу України).

Принципи провадження у справах про адміністративне правопорушення прямо чи опосередковано закріплення в ряді статей Кодексу України про адміністративні правопорушення [0]. Адміністративно-правова наука систематизує ïх наступним чином: «1) принцип законності; 2) принцип охорони інтересів держави і особи; 3) принцип публічності (офіційності); 4) принцип самостійності і незалежності суб’єктів юрисдикції у прийнятті рішень; 5) принцип гласності; 6) принцип поєднання диспозитивності та імперативності; 7) принцип рівності учасників процесу перед законом; 8) принцип оперативності та економічності; 9) принцип провадження адміністративно-деліктного процесу національною мовою; 10) принцип встановлення об'єктивної (матеріальної) істини; 11) принцип права на захист» [0, с. 119].

Зміст принципів державної політики у сфері надання безоплатної правової допомоги як основоположні засади організації функціонування даного інституту було детально розглянуто нами вище.

До принципів організації надання безоплатної правової допомоги слід віднести окремі засади, характерні для тих чи інших процесів, які безпосередньо не пов'язані з наданням правових послуг. Так, наприклад, впровадження стандартів якості надання безоплатної вторинної правової допомоги в цивільному, адміністративному процесах та представництва у кримінальному процесі здійснюється на підставі принципів: «верховенства права, законності, незалежності адвокатської діяльності, конфіденційності, уникнення конфлікту інтересів, пріоритету інтересів клієнта, компетентності та добросовісності у виконанні адвокатом своїх професійних обов'язків» [0]. У свою чергу в п. 3 Порядку й умов укладення контрактів з адвокатами, які надають безоплатну вторинну правову допомогу на постійній основі, та договорів 3 адвокатами, які надають безоплатну вторинну правову допомогу на тимчасовій основі, затверджених постановою Кабінету Міністрів України від 11 січня 2012 р. № 8 наголошено на тому, що окрім законодавчих положень, при укладенні контракту або договору з адвокатом на обов'язковому врахуванні принципу незалежності адвокатської діяльності [15].

Щодо суб'єктивних принципів, то ними повинен керуватись суб'єкт, котрий надає безоплатну правову допомогу. Такі принципи, пов'язані 3 професійною діяльністю того чи іншого суб'єкта, включають морально-етичні аспекти діяльності і відрізняються між собою в залежності від його статусу. Наведемо конкретні приклади. У випадку, якщо (вторинна) безоплатно правова допомога надається адвокатом, останній керується принципами «верховенства права, законності, незалежності, конфіденційності та уникнення конфлікту інтересів» [16] (ч. 1 ст. 4 Закону України «Про адвокатуру та адвокатську діяльність»), а також основними принципами адвокатської етики, що знайшли своє відображення в розділі II Правил адвокатської етики, затверджених 
Вищою кваліфікаційно-дисциплінарною комісією адвокатури та 3'їздом адвокатів України від 17.11.2012 р.: незалежність та свобода адвоката у здійсненні адвокатської діяльності (ст. 6); дотримання законності (ст. 7); пріоритет інтересів клієнта (ст. 8); неприпустимість конфлікту інтересів (ст. 9); конфіденційність (ст. 10); компетентність та добросовісність (ст. 11); повага до адвокатської професії (ст. 12); вимоги до рекламування адвокатської діяльності (ст. 13) [17].

У свою чергу первинна безоплатна правова допомога може надаватись посадовими особами органів місцевого самоврядування, на чому прямо наголошено у п. 2 ч. 1 ст. 9 Закону України «Про безоплатну правову допомогу», які в свою чергу є державними службовцями (п. 11 ч. 3 ст. 3 Закону України «Про державну службу»). Такі особи в своїй професійній діяльності, в тому числі при наданні первинної безоплатної правової допомоги, повинні керуватись принципами: верховенства права; законності; професіоналізму; патріотизму; доброчесності; ефективності; політичної неупередженості; прозорості (ст. 4 Закону України «Про державну службу») [0] та Загальними правилами етичної поведінки державних службовців та посадових осіб місцевого самоврядування [0].

Міжнародні принципи та надання правової допомоги, як загальновизнані всесвітові стандарти характеризуються великою кількістю; найбільш значущі правила знайшли своє відображення в Резолюції 78 (8) «Про безоплатну правову допомогу і юридичні консультації», прийнятій Комітетом Міністрів Ради Європи 2 березня 1978 року, котра передбачає п'ять основних стандартів: 1) жодна особа не може зазнавати обмежень або перешкод щодо користування безоплатною правовою допомогою через причини економічного характеру; 2) такий вид допомоги повинен надаватись компетентною та висококваліфікованою особою; 3) особа повинна бути максимально вільною у виборі суб'єкта надання безоплатної правової допомоги; 4) повне фінансування даної процедури за рахунок коштів держави; 5) здійснення широкої інформаційної політики населення про безоплатну правову допомогу [20]. Одночасно даний перелік стандартів не може вважатись вичерпним, оскільки пов'язаний із захистом прав і свобод особи, професійної діяльності адвокатів і юристів, державної політики у сфері надання правової допомоги.

Висновки. Встановлено, що принципам надання безоплатної правової допомоги притаманний дуалістичний характер: 3 одного боку, це велика кількість принципів, на яких будується і здійснюється надання безоплатної правової допомоги, з іншого - лише ті організаційно-правові засади, на основі яких забезпечується адміністрування даною сферою.

У свою чергу, запропонована вище розширена система надання безоплатної правової допомоги, на наш погляд, може об'єктивно відобразити зміст і призначення цього інституту. Окрім того, вона вміщує широкий перелік засад, які в сукупності забезпечать надання оперативної, професійної та якісної правової допомоги населенню. Законодавче обмеження засад надання без- 
оплатної правової допомоги лише принципами, на підставі яких реалізується державна політика в цій сфері, не в змозі відобразити сутність безоплатної правової дороги, як і не сприяє формуванню розуміння основних аспектів надання правових послуг. Отже, актуальним вбачається розширення законодавчого переліку принципів надання безоплатної правової допомоги шляхом уніфікації основних структурних елементів наведеної вище системи.

\section{Література}

1. Мельничук О. С. Словник іншомовних слів. К., 1974. 775 с.; 2. Даль В.И. Толковый словарь живого великорусского языка: в 4-х т. М.: Гос. изд-во иностр. и нац. слов., 1955. Т. 3. 556 с.; 3. Бусел В. Т. Великий тлумачний словник сучасної української мови. Київ; Ірпінь: Перун, 2005. 1728 с.; 4. Шемшученко Ю. С. Юридична енциклопедія: в 6 т. К.: Вид-во «Українська енциклопедія» імені М. П. Бажана, 1998-2004. Т. 5. 2003. 736 с.; 5. Зайчук О.В. Принципи права в контексті розвитку загальноъ теорії держави і права. Альманах права. 2012. Вип. 3. С. 22-28; 6. Бахновська І.П. Риси принципів права: теоретичні аспекти. Науковий вісник Ужгородського національного університету. Серія: Право. 2013. Вип. 23. Ч. 1. T. 1. С. 18-22; 7. Про безоплатну правову допомогу: закон України від 02.06.2011 № 3460-VI. Відомості Верховної Ради Украӥни. 2011. № 51. Ст. 577; 8. Конституція України від 28.06.1996. № 254к/96-ВР. Відомості Верховної Ради України. 1996. № 30. Ст. 141; 9. Кримінальний процесуальний кодекс України від 13.04.2012 № 4651-VI. Відомості Верховної Ради України. 2013. № 9-10, № 11-12, № 13. Ст. 88; 10. Кодекс адміністративного судочинства України від 06.07.2005 № 2747-IV. Відомості Верховної Ради Украӥни. 2005. № 35-36, № 37. Ст. 446; 11. Цивільний процесуальний кодекс України від 18.03 .2004 р. № 1618-IV. Відомості Верховної Ради України. 2004. № 40-41, 42. Ст. 492; 12. Кодекс України про адміністративні правопорушення від 07.12.1984 № 8073-Х. Відомості Верховної Ради Украӥнської РСР. 1984. Додаток до № 51. Ст. 1122; 13. Колпаков В.К. Адміністративна відповідальність (адміністративно-деліктне право): навчальний посібник. К.: Юрінком Інтер, 2008. 256 с.; 14. Про затвердження Стандартів якості надання безоплатної вторинної правової допомоги у цивільному, адміністративному процесах та представництва у кримінальному процесі: наказ Міністерства юстиції України від 21.12.2017 p. № 4125/5. Офіційний вісник Украӥни. 2017. № 101. Ст. 3137; 15. Про затвердження Порядку і умов укладення контрактів 3 адвокатами, які надають безоплатну вторинну правову допомогу на постійній основі, та договорів з адвокатами, які надають безоплатну вторинну правову допомогу на тимчасовій основі: постанова Кабінету Міністрів України від 11.01.2012 p. № 8. Офіиіийний вісник України. 2012. № 3. Ст. 92; 16. Про адвокатуру та адвокатську діяльність: закон України від 05.07.2012 р. № 5076-VI. Відомості Верховної Ради України. 2013. № 27. Ст. 282; 17. Правила адвокатської етики: Вища кваліфікаційно-дисциплінарна комісія адвокатури, 3’їзд адвокатів України від 17.11.2012 // БД «Законодавство України» / ВР України. URL: http://zakon.rada.gov.ua/rada/show/n0003418-12 (дата звернення: 22.08.2019); 18. Про державну службу: закон України від 10.12.2015 № 889-VIII. Відомості Верховної Ради України. 2016. № 4. Ст. 43; 19. Про затвердження Загальних правил етичної поведінки державних службовців та посадових осіб місцевого самоврядування : наказ Національного агентства України з питань державної служби від 05.08.2016 р. № 158. Офіиійний вісник України. 2016. № 74. Ст. 2493; 20. Резолюція 78 (8) Про безоплатну правову допомогу і юридичні консультації прийнята Комітетом Міністрів Ради Свропи 2 березня 1978 року // БД «Законодавство України» / BP України. URL: http://zakon4.rada.gov.ua/laws/show/994_132 (дата звернення: 30.08.2019). 